\title{
Factors Influencing Coffee Farmers' Decisions to Join Cooperatives
}

\author{
Roland Azibo Balgah ${ }^{1}$ \\ ${ }^{1}$ Senior Lecturer \& Senior Research Fellow, College of Technology, The University of Bamenda, Cameroon, P.O. \\ Box 39, Bambili, NWR, Republic of Cameroon \\ Correspondence: Roland Azibo Balgah, Senior Lecturer \& Senior Research Fellow, College of Technology, The \\ University of Bamenda, Cameroon, P.O. Box 39, Bambili, NWR, Republic of Cameroon. Tel: 237-670-511-067. \\ E-mail: balgahroland@gmail.com
}

\author{
Received: October 11, 2018 Accepted: October 26, 2018 Online Published: November 14, 2018 \\ doi:10.5539/sar.v8n1p42 \\ URL: https://doi.org/10.5539/sar.v8n1p42
}

\begin{abstract}
The role of cooperatives in buffering the effects of imperfect markets on smallholder agriculture especially in developing countries has been widely atoned. However, and in spite of eminent advantages, not all smallholder farmers join cooperatives. We use empirical data from coffee farmers in Northwestern Cameroon to identify key factors driving coffee farmers' decisions to join or not to join a cooperative. Using a standardized questionnaire, data was collected from 140 randomly selected farmers (members and non-members) in contact with North West Cooperative Association Limited (NWCA). Data collection took place in January 2018, with 2017 as the reference period. We use the data to characterize the coffee sector in the region, and to identify key drivers for cooperative membership. $41.4 \%$ and $58.6 \%$ were NWCA members and nonmembers respectively. The area of land under coffee cultivation, dominant income source, household size, experience in coffee farming, and timely payment of farmers' dues by the cooperative were the key factors influencing coffee farmers' decision to join the cooperative or not $(P=0.05)$. Identifying such drivers from farmers' perspectives and informing policy decisions can increase competitive advantage of smallholder farmers and reduce the effects of market imperfection, as embedded in cooperative concept. This should render the concept once more attractive and portray it as a rational option to many smallholder farmers.
\end{abstract}

Keywords: drivers, membership decisions, smallholder farmers, coffee, cooperative

\section{Introduction}

Economists have traditionally paid insufficient attention to the question of what motivates people to join economic organizations, such as cooperatives. Farmers' cooperatives are romanticized to transaction costs and increase the economies of scale, thereby rendering smallholder holder agriculture competitive (World Bank, 2008; Tesfamariam, 2012). In addition, cooperatives can buffer crises, resist the negative effects of rapid and sudden climate change, provide privileged forums for discussing and searching for solutions to common problems faced by farmers, and increases their technical efficiency (Armando, 2009; Abate, Francesconi \& Getnet, 2014). While cooperatives can essentially increase competiveness for small scale producers (World Bank, 2008), their acceptance, establishment, attractiveness and sustainability is a growing concern in many developing countries, especially in the coffee and cocoa sectors. Coffee is the second liquid consumed worldwide after water as a beverage and also the second most traded commodity in the world after oil. Coffee production therefore remains an attractive agricultural sector, in spite of frequent price fluctuations. Coffee farmers in many Sub-Saharan African countries still face high transaction costs which prohibit their access to better-paying markets and thus worsen their poverty levels (Barret, 2008). Lack of information on prices, lack of linkages between farmers and other market actors, credit constraints and other market imperfections push these peasants to sell their crops at the farm gate to intermediaries, often at a low price, and to not take advantage of market opportunities (Fafchamps \& Vargas-Hill, 2005). This could also be associated to the fact that the opportunities offered by fair trade in the coffee business have not been fully exploited by cooperatives especially in developing countries.

According to FAO (2007), fair-trade is an initiative in favor of small producers and salaried workers in the South, for whom the economic and/or social development is limited by the trade conditions (especially vulnerable groups or disadvantaged individuals). In other words, fair trade is a trading partnership, based on dialogue, transparency and respect that seek greater equity in international trade. It contributes to sustainable development 
by offering better trading conditions to, and securing the rights of disadvantaged producers and workers especially in the South. Fair trade organizations (backed by consumers) are actively engaged in supporting producers in awareness raising and in campaigning for changes in the rules and practices of conventional international trade (Pierre, 2007; FLO, 2009). Therefore if an equitable access to the markets under better trade conditions can help them in their development, they can participate in fair trade. This trade guarantees to producers in developing countries the purchase of their products at a "just" price, sheltered from global market fluctuations. Estimates showed that certified sustainable coffee accounted for $9 \%$ of international coffee sales and was projected to increase to $18 \%$ in 2015 (COSA, 2013; Bacon, Robert \& Hannah, 2015). membership in, or the creation of farmer organizations (cooperatives) and the certification of coffee farmers have often been suggested to address the problem of coffee marketing, given their capacities for collective action, as they represent efficient mechanisms for increasing market access and reducing poverty (Birchall, 2003;Poulton, Kydd \&Doward,2006; World Bank, 2008; Bacon et al., 2015).

Cameroon seems to take advantage of the favorable options available for coffee farmers in developing countries. Tuengno (2016) opines that over 25,000 coffee farmers had been certified in Cameroon by 2016. In spite of such efforts, at least two problems still plague the coffee sector. First, production is at best stagnant, and even reducing. Going by global statistics, Cameroon is the $31^{\text {st }}$ most important producer of coffee in the world. Unfortunately, recent statistics from the Cameroon coffee-cocoa board (ONCC, 2018) revealed that coffee produced during the 2016-2017 campaign was only 20,270 tons, representing a decrease of about $20 \%$ compared to the volume produced during the previous campaign. This is the worst performance of registered in the Cameroonian coffee sector and supersedes the 16,142 tons in absolute terms recorded during the 2012-2013 campaign; which was qualified as the worst campaign in the last 50 years (Brice, 2018). Second, the bulk of coffee producers who are smallholders are increasingly de-motivated to join or create cooperatives. This further keeps the country away from reaching the goals contained in the recovery plan according to which the national production should rise to 150,000 tons by 2020 .Statistics on the current number of coffee cooperatives in Cameroon are quite difficult to come by. According to Joitsa, Musima \& Yambene (2015), there are cumulatively about 150 simplified cooperatives and cooperatives with board of directors in Cameroon (Note 1). The most active exporters of coffee in Cameroon include Olam-Cameroon Olam (a subsidiary of Olam International Limited), UTI (Union trading international, UCCAO (Union Centrale des Cooperatives Agricole de l'Ouest), NWCA (North West Cooperative Association), NEALIKO, Hilltop Dynamics, and Alpine Coffee Limited. Cooperatives therefore present a very useful tool in helping coffee farmers escape from poverty and also improve their livelihoods, through collective marketing (ibid). Drop in membership or reluctance to join cooperatives is a call for concern for those interested in poverty alleviation and sustainable development. The need for research that should inform development efforts in the coffee sector is therefore eminent. This paper makes a contribution by characterizing the smallholder coffee sector in Cameroon, as well identifying key factors driving coffee farmers' decision to join cooperatives or not.

\subsection{Problem Statement}

Coffee production and processing plays an important role in many economies. Coffee is grown in over 60 (mostly less developed) countries in Latin America, Asia and Africa, where it lends itself as a source key source of income for over 100 million people (Manning, Boons, von-Hagen \& Reinecke, 2012; Nkechi \& Uchenna, 2015). The bulk of the coffee produced on small farms is consumed out of the production centers. The top coffee consuming countries include the USA, Germany, Japan, Italy and France, in decreasing order of importance (Manning et al., 2012). In order to enhance fair competition, smallholder coffee farmers have often been encouraged to engage in cooperative production and marketing. Many Non Governmental Organizations (NGOs), bilateral or multilateral organizations and national governments have supported, defended or promoted agricultural cooperatives as important institutions to attract higher returns from the coffee and other related sectors (Armando, 2009). Market penetration has also been facilitated by favorable policies, such as fair trade (FAO, 2007, FLO, 2009).

Coffee production is an important cash crop in Cameroon. In 2015 for instance, the government of Cameroon through its Ministries of Agriculture and Rural Development (MINADER), and Scientific Research and Innovation (MINRESI) developed a new strategy for the coffee sector, aimed at motivating farmers to boost up production and accelerate sustained development needed for poverty reduction (Divine, 2014). One key approach here was improving smallholder productivity and commercialization of crops with the help of cooperatives, given the general drop in production orchestrated by serious drop in coffee prices in the late 1980s and early 1990s, as a consequence of structural adjustment programs. Despite all these efforts, many coffee farmers have been reluctant to join or create cooperatives, partly because of the sharp decline in the marketing of 
coffee through cooperatives as a result of the liberalization of the coffee sector in the late 90's (Momo-Lekane, 2016). Using the case of the North West Cooperative Association (NWCA) in the North West Region of Cameroon - a principal coffee producing region in the country, this article characterizes the coffee sector and identifies key factors(de)motivating coffee farmers to join cooperatives.

\subsection{The Concept of Cooperatives Revisited}

A cooperative is a legal entity owned and democratically controlled by its members. Members often have a close association with the enterprise as producers to consumers of its products or services or as its employees (Hueth \& Marcoul, 2009; Nigusie, 2013). The spirit of association is essential to human progress since the beginning of human society. However, the innumerable forms of cooperative action in socio-economic life are contingent on multiple cooperation instincts and the innate corporate feelings which human beings adopt. Good cooperation from social feeling and the economic rationale of endless effects of collective action, have led to the beginning of formal cooperation (Birchall \& Simmons, 2008; Nigusie, 2010 \& 2013). As a result, certain values and principles (self help, self-responsibility, democracy, quality, equity and solidarity) have emerged that guide the operation of cooperative behavior. In the tradition of their founders, cooperative members believe in the ethical values of honesty, openness, social responsibility and caring for others. According to Nigusie (2013), cooperatives are therefore democratic organizations controlled by their members, who actively participate in setting policies and making decisions. In more democratic cooperatives, men and women serving as elected representatives are accountable to the members of the cooperative. In this sense, members have equal voting rights and thus contribute equitably to the capital of the cooperative. In the case of coffee production and marketing, cooperatives should support smallholder farmers to increase their bargaining power and become more competitive (Joitsa et al., 2015).

Based on the aforementioned, it is logical to conceptualize cooperatives as social enterprises which can potentially help the poor to break through the vicious cycle of poverty (Zeuli\&Cropp, 2004;Birchall\&Simmons, 2008;Birchall\&Ketilson, 2009;Bernard, Abate, \& Lemma, 2013;Divine, 2014; Abate et al., 2014). This probably explains why Kumar, Wankhede and Gena (2015) describe a cooperative as an autonomous association of persons united voluntarily to meet their common economic, social and cultural needs and aspirations through a jointly-owned and democratically-controlled enterprise.

Enormous research exists on the roles of cooperatives in community development in countries around the world in general, and their specific contributions to agricultural productivity and poverty reduction (Frederick, 1997; Zeuli \& Cropp, 2004; Birchall \& Simmons, 2008; Birchall \& Ketilson, 2009; Kumar et al., 2015; Hasen \& Mekonnen, 2017). Past research done for instance by Fredrick (1997) on the cooperative movement in western Malaysia showed differences between cooperative policies before and after independence. He attributed community social and economic impacts to increased membership in cooperatives. Being voluntary, democratic and self -controlled, cooperatives offer institutional forms through which local communities gain control over productive resources and activities from which they derive their livelihoods (Wayama, Develtere \& Pollet, 2009; Getnet \& Anullo, 2012; Ito, Bao \& Su, 2012; Nkechi \& Uchenna, 2015). Cooperatives provide services ranging from group purchasing discounts, access to markets, better product information and technology, through risk-sharing and reduced transaction costs, to increased farm income and joint ownership of common facilities (Jamilah, 2006; Markelova \& Mwangi, 2010; Lund, 2013; Nkechi \& Uchenna, 2015; Hasen \& Mekonnen, 2017). Jamilah (2006) for instance studied the Fisherman's cooperatives in Malaysia and found them to promote both economic and social benefits to their members.

For some scholars, cooperatives conduct business in a transformational development way, by allowing members to take charge of their own destinies and bring desired services to their communities (Osterberg, Hakelius, \& Nilsson, 2007; Hasen \& Mekonnen, 2017). In addition, cooperatives facilitate decision making, build trust and accountability through democratic processes, while generating profits and accumulating/protecting assets at the community level (Osterberg et al., 2007; Nkechi \& Uchenna, 2015). Trust is a crucial factor, as it determines group cohesion and subsequent levels of performance of cooperatives.

Several studies suggest that membership in cooperatives improves the commercialization behavior of smallholder farmers; whichin turn enhances farm productivity and farm income at micro level, and food security and allocative efficiency at macro level (Bernard \& Spielman, 2009;Markelova\&Mwangi, 2010; Abate et al., 2014). Cooperatives also reduce transaction costs and information asymmetry by strengthening farmers' negotiation ability (Hellin, Lundy, \& Meijer, 2009; Trebbin, 2014). This will, in turn, increase the income of farmers (members) through their bargaining power, which increases the price of their products and lowers the costs of purchased inputs. Furthermore, inclusive cooperatives play a strong social role in improving gender relations and help 
women create safe spaces to build their social solidarity and problem-solving capacity, particularly in all-female cooperatives (Baden \& Pionetti, 2011). Some scholars therefore, rightfully contend that cooperation amongst members could be a way out in enhancing cooperative benefits and reducing membership problems (Zeuli \& Bentacor, 2005; Kumar et al., 2015). This can be crucial for the survival of the largely smallholder-oriented coffee sector in Africa, whose current production is largely under expectation.

According to the International Coffee Council (2015), coffee is grown in 25 countries in Africa. Despite this numerical advantage, Africa's share of world production of coffee dropped from $24.9 \%$ to an average of $14 \%$ in 2015. One of the reasons for this drop was the shortage of efficient farmer organizations which can act as conduits to supply essential support services and other initiatives to develop the coffee sector. In countries where a free marketing system applies, prices are dictated by the international market and transmitted locally through either an auction system (the case of Ethiopia, Kenya, and Tanzania) or direct sales (the case of Rwanda, Uganda, etc.). As reported by the Centre for International Development Issues Nijmegen (CIDIN) (2014), farmers in Uganda, Kenya and Ethiopia have developed a high amount of certainty that they can sell their coffee throughout the coffee season at a decent price if they go through coffee cooperatives. However in order to reduce the risk of opportunistic behavior (e.g. side-selling) the identity of members matter to build trust and long-term relations in the cooperatives. Furthermore, trust lowers enforcement and thus transaction costs (Keefer \& Knack, 2005). Chaddad (2012) recognized that cooperatives use the style of neoclassical contract as they blend informal mechanisms based on trust and reputation in repeated transactions with formal governance mechanisms (such as a Board of Directors elected by members).

For any cooperative or association to exist and operate, there are certain laws and policies that they must abide by. Cooperative policies, whether published as a dedicated document, enshrined in overarching public documents such as the country's Constitution or national development plan; or derived from policy statements and declarations; are of course strongly influenced by the relationship between cooperatives and the state. In the post-colonial period, few countries issued dedicated cooperative development policies, but many integrated cooperative promotion as a key strategy into their national development policies, going as far as enforcing the "cooperativization" of the entire nation, as was the case for instance in Tanzania and Tunisia (CIDIN, 2014). In these cases as in many others, cooperative policies were motivated by political goals rather than the desire to create a conducive environment for the emergence of genuine cooperatives. Moreover, such policies were devised without any involvement of the people most concerned, i.e. the cooperative members.

The collapse of state-sponsored cooperative movements in the 1990s, the process of economic liberalization and deregulation, as well as ever growing calls for democratization, multi-partism and popular participation led to the revision of cooperative laws in most countries. Many Governments decided to anchor those laws in to their national cooperative development policies which, in most cases, were designed in close consultation with cooperative organizations, cooperative members and civil society organizations. By 2014, over thirty African countries had adopted cooperative development policies (ILO, 2014).

Cooperatives are very important but not the only organizational forms that can lever the poor out of poverty. Other traditional systems of cooperation (or associations), mutuality, reciprocity and solidarity exist in all African societies, and they have remained vibrant till today, in particular in rural areas and in the urban informal economy. Well known are the rotating savings and credit associations or ROSCAs (also known as "tontines" in French speaking Africa) which are omnipresent on the continent and involve large numbers of people.More often than not, they include an element of mutual social assistance in addition to savings and credit functions. Of great importance is the social aspect of these associations, as they provide opportunities to meet and celebrate as a group on a regular basis. Burial societies, which can be considered as a form of micro-insurance, are prevalent especially in Southern Africa and Ethiopia. Mutual work-sharing schemes for large, labor-intensive ventures such as house construction, land clearing or crop harvesting can be found everywhere on the continent. Other traditional forms of cooperation provide social assistance to community members in need (a practice known as "Ubuntu" in Southern Africa, or "Umoja" in East Africa).Such ancient traditions have been successfully adjusted to modern times, to urban societies and to the informal economy of many African countries (Develtere, Pollet \& Wanyama, 2008). In these traditional associations, social capital and social control are of paramount importance. These groups/associations may handle large amounts of cashwithout any collateral or security. Transactions are therefore often based on trust and social cohesion, and not necessarily onwritten agreements or contracts. The groups are often temporary or periodic in nature and emerge when needs or opportunities arise. It is worth mentioning that these groups seldom build secondary bodies such as unions and federations. However, these traditional African self-help groups share many of the values and principles of modern cooperatives but do not replace the latter. Rather, they co-exist with them even today. Cooperatives work well in traditional societies 
where mutuality and informal cooperative activities are embedded in the form of common property, such as shared water and grazing rights and informal financial sharing among vendors in markets. In typical African societies, the success for instance of farmer cooperatives can be partially explained by their similarity to the traditional rotating savings and credit associations found in most rural communities (Develtere et al., 2008; ILO, 2014).

Since its inception, the cooperative sector in Cameroon has been guided by a number of legal frameworks (Note 2). In spite of slight differences, these laws and their accompanying decrees of application emphasize certain general aspects of cooperatives, particularly democratic control, joint ownership, relative autonomy and voluntary nature. Except for registration fees, members of agricultural cooperatives are generally not expected to pay any form of taxes (Department of Cooperation and Mutuality, 1981;Joitsa et al., 2015).

It can therefore be concluded that joining cooperatives is largely beneficial especially to smallholder coffee farmers in Cameroon. If Cameroonian farmers are rational they should demonstrate stronger preference to join cooperatives. Deviations from this "ideal" situation provided strong justification for this research.

\subsection{What Drives Farmers' Decision to Join Cooperatives?}

The topical literature identifies several reasons why famers decide to or not to join a cooperative. Using a Probit model in Rwanda, Divine (2014) for instance found out that the greater the number of cooperatives relative to the number of processors (or farmers), the more they willingness to be members of the cooperative. This, he contends, is driven by the greater probability to directly participate in cooperative activities. Farmers with more assets are slightly less inclined to join cooperatives, unless the probability to directly participate in the cooperative's activities is high. Okwoche, Osugura and Chukudi (2012) also reported that farmers joined the farmers' cooperative societies mainly to have access to financial credit. Lerman and Ruben (2005) on their part explained that access to non-farm income encourages peasant farmers to join the cooperatives because they are less exposed to risks. In another study, Jussila, Byme and Tuominen (2012) revealed that people become cooperative members essentially to enhance social status and take decisions that favor their preferences.

Fanaye and Thomas (2012) applied Tobit and Logit models to analyze the determinants female membership in agricultural cooperatives in Ethiopia. They observe that the organizational form of cooperatives affects the proportion of female members. In addition, women decided to join cooperatives when the expected utility exceeded the cost of membership (e.g. membership fee).

Other studies (e.g Bernard \& Spielman, 2009; Asante, Sefa \& Saprong, 2011; Azmah, Fatimah, Rohana \& Rosita, 2012) have shown that the age of the farmer is positively and significantly correlated with cooperative membership. As the farmer gets older, (s) he is likely to join a cooperative mainly secure a market for his/her increasing output, or for old age (security) reasons. Educational level of the household head is another personal variable that positively determines cooperative membership (Bernard \& Spielman, 2009; Verhofstadt \& Maertens, 2014; Mojo, Fischer \& Degefe, 2015). According to Verhofstadt and Maertens (2014), as farmers become more educated on the benefits of cooperatives, they are likely to join. The sex of the household head can also influence membership decision. As confirmed by Abebaw and Haile (2013), male-headed households are more likely to participate in agricultural cooperatives than female-headed households, since men generally undertake less reproductive functions (Balgah, 2016).

Some studies demonstrate that household size affects the membership decisions (Bernard \& Spielman, 2009, Mojo et al., 2015). There contentions are however mixed. The influenced of assets owned by farmers is equally mixed. For instance, size of owned land and livestock holdings have been found in a number of studies to positively influence cooperative membership (Asante et al., 2011; Bagher, 2011; Francesconi \& Heerink, 2011; Abebaw\& Haile, 2013; Mojo et al., 2015). On the contrary, Karli, Bilgic and Celik (2006) and Verhofstadt and Maertens (2014) indicate that owning more land decreases the likelihood of being a cooperative member. Asante et al (2011) and Bagher (2011) also showed that access to credit/loan and income influenced farmers' decision to join farmer based organizations.

In addition to household and personal factors, institutional variables can also influence participation in cooperatives. For example Fischer and Qaim (2012), Abebaw and Haile (2013), and Verhofstadt and Maertens (2014) indicate that distance to the nearest road has a negative and significant relationship with households' participation in cooperatives. This is logical, as marketing difficulties are minimized by access to major roads. Additionally, proximity to the cooperative office has a significant influence indicating the effects of farmers' geographic locations on participation decisions (Mojo et al., 2015).

In spite of some trends, the studies summarized above seem to indicate that the determinants for individual 
membership decisions are generally context-specific (Manning et al., 2012).Since the 2013-2014 campaign in Cameroon which restored the hopes of producers (with production reaching 32,800 tons), the national production has rather slumped by more than 12,500 tons. According to local experts, this decrease could be attributed to the unavailability of seeds, the use of old varieties with meager output, the high cost of inputs, and the old age of plantations and of the producers. There is also the lack of interest of farmers to join cooperatives as well as in coffee planting since its price is less profitable, compared to crops like cocoa. Indeed, the price of coffee is not in line with the volume of work required by coffee production (Brice, 2018). We therefore examine these and other factors in the Cameroonian context, given the rapid slum in coffee production and the increasing reluctance of coffee farmers to join cooperatives.

\section{Research Methodology}

\subsection{Brief Description of the Study Area}

The North West region of Cameroon is largely agricultural, and is still a major coffee producing region in Cameroon (Balgah, 2016). The North West Cooperative Association (NWCA) located at the heart of Bamenda the regional capital is the most important coffee farmers' cooperative in the region. NWCA was purposively selected for the study because it deals with both members and nonmembers. According to NWCA management, the decision to collaborate even with nonmembers has been driven by the rapid drastic drop in registered members in the last 2 decades. For the sake of this study, it provides us with a sampling frame that allows access to both members and nonmembers, in our attempt to identify which factors are critical in the decision-making process.

\subsection{Sampling Procedures}

Multi-stage sampling approach was applied. In the first stage, we purposively sampled NWCA, based on the fact that it trades with both members and nonmembers. As such, access to the two types of farmers will be easier. Secondly, NWCA is the only farmers' cooperative working with coffee farmers located in all four (of the seven) divisions in the North West region of Cameroon, where coffee production is widely done. The sampled farmers was therefore (at least to a large extent) representative of the farmers in the research region. However, due to time and financial constraints two of the four divisions where NWCA operates were randomly selected for the data collection. 140 farmers were then randomly selected from the two divisions for data collection, irrespective of whether they were members or not. The sampling frame was obtained from the management of NWCA. Information from NWCA suggested that there were 230 farmers with which the cooperative actively collaborated in the 2017 coffee farming season. A total of 140 farmers (60.9\%) were then randomly selected, irrespective of whether they were registered members of NWCA or not. The major criterion was active cooperation with NWCA in the 2017 coffee farming season. Nevertheless, the question on membership with NWCA was asked to all respondents, as this was needed later for the differentiated analysis.

\subsection{Data Source and Method of Data Collection}

In this study, both primary and secondary data was collected, using a mixed methods approach. Quantitative primary data was collected using a structured questionnaire with both opened and closed ended questions. Information on household demographics, coffee production systems, coffee marketing, harvest, sales and incomes from coffee as well as key reasons for joining and for not joining NWCA were collected. Qualitative data was obtained using Participatory Rural Appraisal (PRA) tools, particularly focus group discussion, key informant interviews and field observations. Qualitative data was mainly collected to complement the standardized questionnaire. Secondary data was collected from relevant sources such as the internet, journal papers and books in NWCA office.

\subsection{Data Analysis}

Both descriptive statistics and econometric analyses were performed.

\subsubsection{Descriptive Statistics}

Descriptive statistics (frequencies, percentages and means) were used to characterize coffee farmers and the coffee sector in North West Cameroon. The results are presented and discussed in the first part of the results and discussion section.

\subsubsection{Econometric Analysis}

In order to identify which factors robustly affect farmer's decision to become a member or not of NWCA, a cumulative logistic model is employed. The logistic model (based on Bogale\&Shimelis, 2009) can be econometrically specified as follows: 


$$
\mathrm{Pi}=\mathrm{F}(\mathrm{Zi})=\frac{1}{1+\mathrm{e}^{-(\alpha+\Sigma \beta i X i)}}
$$

Where $\mathrm{P}_{i}$ is the probability that an individual becomes a member given $\mathrm{X}_{\mathrm{i}}$ (the $\mathrm{i}^{\text {th }}$ explanatory variables), $\alpha$ and $\beta_{\mathrm{i}}$ are regression parameters to be estimated, $e$ is the base of the natural logarithm and $Z_{i}$ is the odds ratio of the probability that the farmer would become a member. For easy interpretation of the coefficients, the logistic model could be written as:

$$
\left(\frac{P_{\mathrm{i}}}{1-P_{\mathrm{i}}}\right)=\mathrm{e}^{\mathrm{Zi}}
$$

Where $\mathrm{Pi}$ is the probability that the farmer would become a member and $1-\mathrm{P}_{\mathrm{i}}$ the probability that the farmer will not become a member of NWCA

Taking the natural logarithm of equation (2) therefore yields:

$$
\ln \left(\frac{P_{\mathrm{i}}}{1-P_{\mathrm{i}}}\right)=\mathrm{Zi}=\alpha+\beta 1 \mathrm{X} 1+\beta 2 \mathrm{X} 2+\cdots \cdots+\beta \mathrm{mXm}
$$

To conclude, the following Logit model will be used:

$$
\mathrm{Z}_{\mathrm{i}}=\alpha+\mathrm{X}_{\mathrm{f}} \beta_{\mathrm{f}}+\mathrm{X}_{\mathrm{g}} \beta_{\mathrm{g}}+\mathrm{X}_{\mathrm{c}} \beta_{\mathrm{c}}+\mathrm{X}_{\mathrm{n}} \beta_{\mathrm{n}}
$$

Where $\mathrm{Zi}=$ probability that farmer will become a member of NWCA

$X_{\mathrm{f}}, X_{\mathrm{g}}, \mathrm{X}_{\mathrm{c}}$ and $\mathrm{X}_{\mathrm{n}}$ are the different independent variables and $\alpha$ and $\beta$ are regression parameters to be estimated.

Both descriptive and econometric analyses were performed using the Statistical Package for Social Sciences (SPSS) version 20.0, and Microsoft excel spread sheet 2010. All the descriptive and inferential statistics performed in this study was done at the $95 \%$ confidence interval $(\alpha=0.05)$. Analyses of the socio-economic characteristics of coffee farmers and the coffee were first done. Logistic regression analysis was then applied to ascertain the factors that influence membership of coffee farmers in NWCA.

The student t-test was used to verify the lone hypothesis in this study. Based on previous studies (e.g. Karantininsis, 2007; Chaddad, 2012), it was hypothesized that farm sizes for members would be significantly higher than those of non-members. This hypothesis is based on the assumption that a broader asset base creates stronger trust between the cooperative and the member, making membership attractive to both parties (Hasen $\&$ Mekonnen, 2017). Results are presented and discussed in the next section.

\section{Results and Discussion}

\subsection{Socio-economic Description of Sampled Coffee Farmers}

Our random sample of coffee farmers was dominated by male farmers $(65 \%)$. The rest (35\%) were female. This trend is consistent with previous findings in developing countries, contending a consistently high male dominance in economic farm enterprises (e.g. coffee production), as women tend to be more engaged in reproductive and non-economic activities than men (see for instance, Balgah, 2016).

The cumulative bulk of coffee farmers (almost 56\%) had no formal schooling or had only completed primary school. The relatively educated (secondary school and above) constituted less than $45 \%$ (Figure 1). This is likely to have repercussions in the production process, given that coffee is mostly consumed out of production centers, by countries that place heavy emphasis on high quality (Manning et al. 2012). In addition, 100\% of all respondents heavily rely on coffee farming as a major source of household income. The implications of fluctuations in coffee yields and prices on the livelihoods of the coffee farmers are therefore imaginable.

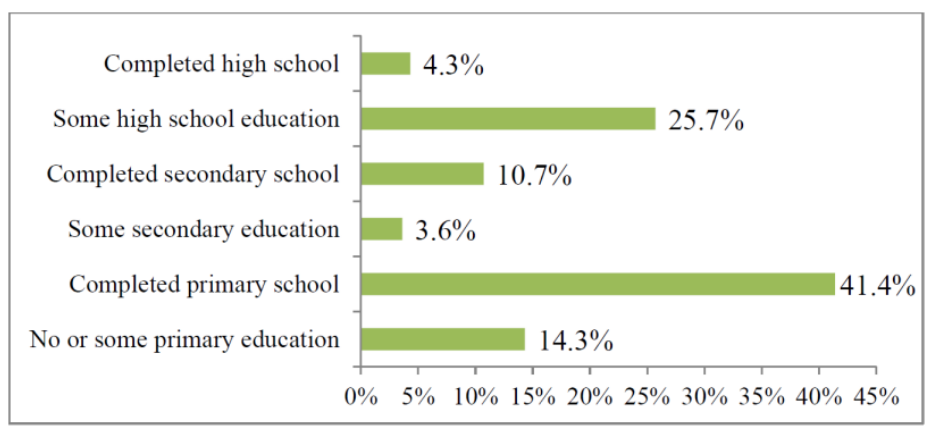

Figure 1. Educational achievement of farmers 
Additional demographic characteristics of coffee farmers are presented in table 1.The youngest farmer interviewed was 35 years old while the oldest was 90 . The mean household size was 9 , with a range of 3 to 21 . Given that coffee farming is intensive, and that smallholder farms often draw on family labor (Ngwa \& Balgah, 2016), larger households can have larger coffee farms, as farm size likely to positively correlate with household size. The mean household estimated monthly income is around 129000 (US\$226.6). Dividing this by the mean household size (9) produces a monthly per capita income of 14,335 (US\$25.2). This suggests that on average, coffee farmers live below the poverty line of US $\$ 1 /$ day. Low investment in the coffee value chain is therefore a logical expectation, as (1) farmers are too poor to invest, given that they are generally poor; and (2) if discounted long term benefits do not supersede current preference for survival and leisure. The second point seems to also obtain in our case study. For instance, the annual expenditures on clothing and footwear of 117730 (US\$206.8) represent almost $8 \%$ of the mean annual calculated household income of FCFA 1543500 (US\$ 2711.2). At the same time, information obtained from key informant interviews suggests that investments on coffee farms per annum are generally very low, ranging from a minimum of FCFA 0 (US\$ 0) to a maximum of FCFA 90.000 (US\$ 158.1).The investments are largely limited to farm inputs that enhance short term benefits, such as fertilizers $(\approx 70 \%)$, payment for periodic (external) labor, especially during fertilizer application, pruning and harvesting $(20 \%)$, purchase of basic farm tools like hand machetes $(\approx 7 \%)$ and pesticides $(\approx 3 \%)$. Farmers generally depend on government and NGO support services for long term investments, such as improved, high yielding varieties, technical support in the form of capacity building and additional material cum financial support. The mean coffee farm size of $6 \mathrm{Ha}$ is slightly deceptive. This would even be smaller, considering that (1)coffee is just one crop cultivated in the dominantly complex, mixed farming systems characteristic of North West Cameroon; the cultivated plots are under different property rights regimes (traditional versus legal; owned, rented, leased, etc), largely biased against women and the cultivation of permanent crops such as coffee (Balgah, 2016). The rich mean experience ( 25 years) continues to be an endogenous asset for coffee production in the research region.

Table 1. Demographic characteristics of sampled coffee farmers

\begin{tabular}{lcccc}
\hline Household variable & Minimum & Maximum & Mean & Std. Deviation \\
\hline Age of coffee farmer & 35 & 90 & 58 & 12.731 \\
Estimated monthly income (FCFA) & 5000 & 500,000 & 128,625 & 121,640 \\
Annual expenditure on clothing & 15000 & 700,000 & 117,730 & 99,895 \\
and footwear (FCFA) & 3 & 21 & 9 & 2.895 \\
Household size & .5 & 15 & 6 & 3.1556 \\
Farm size (Ha) & 1 & 12 & 4 & 2.934 \\
Number of plots & 1 & 69 & 25 & 14.475 \\
Experience as coffee farmer (Years) & & & &
\end{tabular}

Notes:

1. Mean values were rounded up to the nearest convenient number or existing currency

2. FCFA = Franc de la Communauté Financièred' Afrique

3. 1US\$ is equivalent to FCFA 569.3 (www.xe.com, of 07.10.2018)

\subsection{Production System Adopted by Coffee Farmers, Investments and Returns}

Our results show that coffee farmers in the two divisions grow coffee together with other crops. These crops include maize, beans, cocoyam, yams, plantain, banana, cassava, sweet potato, Irish potato, vegetables and fruit trees such as oranges and pear. As mentioned by all the farmers, the main reason for cultivating coffee is for income generation. However to reduce risks and enhance food security, coffee farming is integrated with other food crops. Over $60 \%$ of all coffee farmers higher labor periodically, for intensive activities such as pruning, fertilizer/chemical application and harvesting. This labor is often used quite efficiently, as other crops in the mixed cropping systems often benefit from such additional inputs. Almost $80 \%$ of all coffee farmers are credit-constrained (Figure 2). It should be possible to obtain some form of credits from the farmers' cooperatives. Yet, not all the coffee farmers get interested. A focused group discussion with farmers who did not obtain any credit, although they needed it revealed that many coffee farmers in the region are risk-averse, mainly as a result of unpredicted climatic conditions and high volatility in coffee prices. A consequence is very low financial investments in coffee farms (and low returns per hectare per year), as indicated in Table 2. 


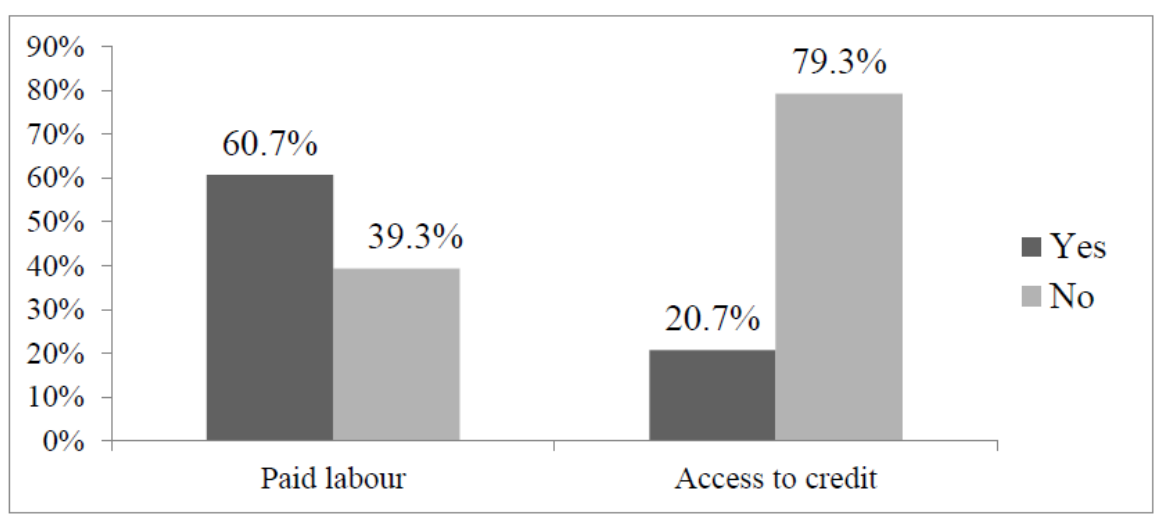

Figure 2. Accessibility to farm inputs

Table 2. Estimated cash investments and returns from coffee farm per season and year

\begin{tabular}{|c|c|c|c|c|}
\hline & Minimum & Maximum & Mean & Std. Deviation \\
\hline Total cost of paid labor (1) & 0 & 25,000 & 1,700 & 3,070 \\
\hline Total other (variable) costs (2) & 0 & 150,000 & 22,020 & 33,105 \\
\hline $\begin{array}{l}\text { Quantity of marketable coffee beans } \\
\text { produced }(\mathrm{Kg}) \text { in } 2017(3)\end{array}$ & 100 & 3100 & 600 & 460 \\
\hline $\begin{array}{l}\text { Calculated gross output from sales of } \\
\text { coffee beans (2017) (4) }\end{array}$ & 15,000 & 465,000 & 90,000 & NA \\
\hline Gross margin (2017) & 15,000 & 290,000 & 66,280 & NA \\
\hline
\end{tabular}

Considering the mean coffee farm size of 6 hectares (Table 1), a mean of harvest $600 \mathrm{Kg}$ represents only $100 \mathrm{~kg}$ of coffee beans per hectare and year. Based on a mean selling price of FCFA 150/Kg of processed beans, the annual estimated gross outputs from coffee production were then calculated (Table 2)

The Gross margin was calculated as follows:

$$
\text { Gross margin }=\text { Gross output }- \text { Total variable costs }
$$

Where:

Gross output = Quantity in Kg in 2017(3) x Sales price of coffee beans per Kg in 2017 (4); and

Total variable costs $=$ total cost of paid labor $(1)+$ other variable costs (2)

Positive gross margins were observed, irrespective of farm size and level of external inputs (table 2). Nevertheless, the total gross margin tended to increase with farm size. The larger the farm size therefore, the more coffee farmers are likely to make money. Thus while risk taking farmers are likely to engage in higher risk-higher-return activities, risk-averse ones may prefer low external input systems (Balgah, 2018). Such attitudes may span into the decision to join cooperatives or not, or even to sell their produce through cooperatives or not. The level of risk assessment is therefore likely to be key variable influencing coffee farmers' decisions to join cooperatives or not. This assessment, which is largely subjective, will vary from one farmer to the next.

\subsection{Preference for Coffee Marketing Channels}

Figure 3 presents the marketing channel used by sampled coffee farmers in 2017. The majority of interviewed farmers (44.5\%) sold to independent traders. The second choice of market outlet was NWCA (41.4\%). However, over $14 \%$ of interviewees sold their coffee a cooperative union other than NWCA. 


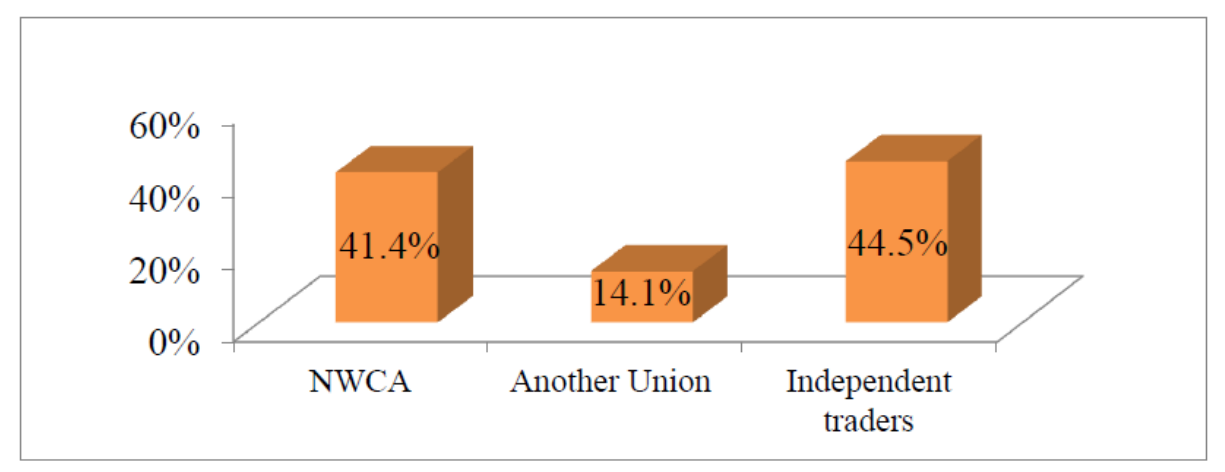

Figure 3. Channel used to market coffee beans in 2017

\subsection{Market Information Sources and Marketed Products}

It is worth mentioning that $38.6 \%$ of coffee farmers got market information from NWCA. $21.4 \%$ of them farmers received this information from other formal sources (e.g. print media and radio), while some $4.3 \%$ of the farmers rely on their fellow colleagues for the right information. To sell their coffee, most of the farmers (97\%) sell their coffee in a dried state while only $2.3 \%$ sell coffee in both the cherries and dried state.

Another interesting observation from this research work was the fact that only 55\% of the farmers acknowledged to the fact that their money is paid in time whether from NWCA, other unions or from the independent traders. Because of this delay in payments, these farmers now have mixed plans for the future of their coffee plantations, as presented in figure 4 .

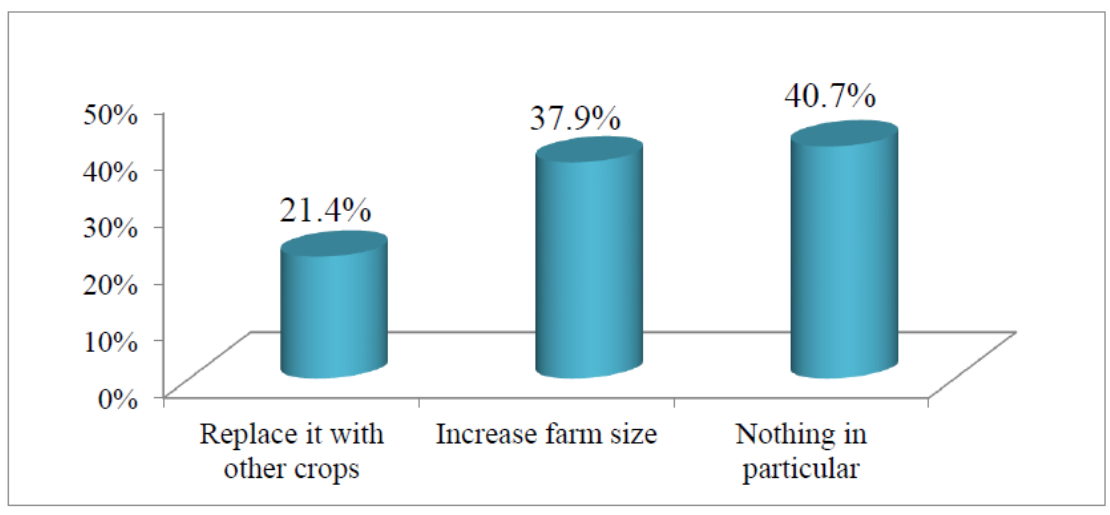

Figure 4. Farmers' future plans for coffee farm

It can be inferred from figure 8 that the majority of the farmers $(\approx 41 \%)$ presently have no future plans for their coffee farms except to continue cultivating coffee. However, around $21 . \%$ of the farmers plan to replace their coffee farms with other food crops probably because coffee harvest is low as a result of low soil fertility, lack of inputs as well as limited access to financial credit. On the other hand, almost $\approx 38 \%$ of the farmers having reaped the benefits of coffee cultivation plan rather increase their coffee farms in the future.

\subsection{Factors Influencing Membership in NWCA}

Initial analysis of membership revealed that only $40 \%$ of all interviewed farmers are current members of NWCA. $13.6 \%$ of the farmers were former members and $24.3 \%$ belonged to other cooperatives. The rest $(22.1 \%)$ are still to become members of any cooperative. Key informant interviews revealed that many farmers joined cooperatives expecting some extra financial benefits from the cooperatives. However, at the time of interview, $47.9 \%$ had received farm inputs; $39.3 \%$ training on coffee production, and only $2.9 \%$ financial credits. Limited access to credit probably creates disincentive for cooperative membership. Additional disincentives mentioned during key informant interviews included higher costs for farm inputs compared to market prices, delays in payment of dues, poor leadership by cooperative and high membership fees in descending order of importance.

Based on the above results, a binary logistic regression analysis was adopted for the analysis. The dependent variable being a member of NWCA took 1 for yes and 0 otherwise. The regression analysis was conducted using 
11 explanatory variables, in order to establish their strengths and directions in influencing membership. The attributes of our model are presented in tables 3, 4 and 5 .

Table 3. Omnibus Test of Model Coefficients

\begin{tabular}{llcc}
\hline Model type & Chi-square & Df & Sig. \\
\hline Step & 67.295 & 10 & .000 \\
Block & 67.295 & 10 & .000 \\
Model & 67.295 & 10 & .000 \\
\hline
\end{tabular}

Table 4. Model Summary

\begin{tabular}{llll}
\hline Step & -2 Log likelihood & Cox \& Snell R Square & Nagelkerke R Square \\
\hline 1 & $53.057^{\mathrm{a}}$ & .535 & .717 \\
\hline
\end{tabular}

a. Estimation terminated at iteration number 20 because maximum iterations have been reached.

As shown in table 3 above, there is a significant relationship between the dependent variable (being a member of NWCA $)$ and the selected independent variables used in the model $\left(\mathrm{X}^{2}=67.295, \mathrm{P}=0.000\right)$. In addition, table 4 suggests that the variables retained in our model explain almost $72 \%$ of the decisions to join the test coffee farmers' cooperative. The degree of influence of individual independent variables on the membership decisions are presented in table 5 .

Table 5. Regression Results

\begin{tabular}{lllllll}
\hline Variable & B & S.E. & Wald & df & Sig. & $\operatorname{Exp}(\mathrm{B})$ \\
\hline Age of farmer & -.143 & .061 & 5.504 & 10 & .019 & .867 \\
Farm size & .174 & .160 & 1.186 & 10 & .276 & 1.190 \\
Number of plots & -.167 & .142 & 1.371 & 10 & .242 & .846 \\
Access to credit & -.281 & 1.134 & .061 & 10 & .804 & .755 \\
Agriculture as main occupation & 18.767 & 40192.9 & .000 & 10 & 1.000 & 14.142 \\
Household size & .107 & .153 & .485 & 10 & .486 & 1.113 \\
Monthly income & .000 & .000 & 8.840 & 10 & .003 & 1.000 \\
Level of education & -.164 & .287 & .326 & 10 & .568 & .849 \\
Gender & -1.824 & .941 & 3.756 & 10 & .053 & .161 \\
Farming experience & .047 & .041 & 1.304 & 10 & .253 & 1.048 \\
Pay dues on time & 5.637 & 1.957 & 8.293 & 10 & .004 & 280.622 \\
Constant & 3.852 & 3.312 & 1.353 & 10 & .245 & 47.083 \\
\hline
\end{tabular}

The beta values indicate that 5 of the 11 tested variables, namely coffee farm size, agriculture as main livelihood source, household size, experience as a coffee farmer and timely payment farmers' dues by the cooperative positively contribute to the decision to join the cooperative. The age of the farmer, number of plots owned, access to credit, level of education of the farmer and the gender of the farmer negatively affected membership decisions. Surprisingly, the household monthly income appears to have no influence on the decisions of the farmers to become members of NWCA $(B=0.000, P=0.003)$. This particular result is in line with that of Balgah, Mbue, Kimengsi and Ngwa (2016); and Ngwa and Balgah (2016) who found out that the household income had no influence on the factors contributing to the adoption of informal mechanisms by disaster victims in Cameroon and the factors contributing to livelihood security among disaster victims in rural Cameroon respectively. On the other hand, it contradicts that of Bagher (2011) who contended that farmers' incomes have a direct impact on their membership decisions and level of participation in cooperative activities. A possible explanation for such a result is that the income maybe normally distributed among the coffee farmers (who were generally poor), and therefore does not lend itself as key decision making factor for membership into cooperatives.

The positive effect of farm size on membership decision is in line with the works of Asante et al (2011) in Ghana, Thorp, Stewart and Heyer (2005), Francesconi and Heerinck (2010), and Hasen and Mekonnen (2017) in Ethiopia; who revealed that the poorest farmers are usually excluded from agricultural cooperatives. This is reasonable, as production on very small farmers may be too small to justify joining a cooperative. Ito et al (2012) also vindicated that smallholder farmers usually opt to self-exclude from participating in agricultural cooperatives especially when the costs of membership are greater than the returns obtained from membership. On the other hand, Verhofstadt 
and Martens (2014) indicated that owning more land decreases the likelihood of being a cooperative member. Cooperatives have the advantage with respect to transactions that involve specific joint-investments, and also when parties are involved in long-term relations. This as explained by Ménard (2004) and Karantininis (2007) pushes farmers to rely heavily on important assets such as land holdings and associations (cooperatives) which acts as informal safeguards.

The positive role played by the household size is logical, given the availability of "costless" labor. Similar trends have been previously reported (see for instance Bernard \&Spielman, 2009, and Mojo et al. 2015). Contradictions also exist (e.g. Hasen \& Mekonnen, 2017) results on factors influence farmers' decisions to join cooperatives in Eastern Ethiopia).

Although relatively new, the timely payment of farmers' dues by the cooperative was found to be a significant contributor to the membership decisions of coffee farmers to join NWCA ( $\mathrm{B}=5.637, \mathrm{p}=0.04)$.

It is observed from table 5 that a one unit increase in area of land used for coffee farming for instance will increase the probability that the farmer will become a member of NWCA by 1.19 times. Similarly, as the number of years the farmer has been cultivating coffee as well as the size of the household of the farmer increases by one unit, the probability that the farmer will become a member of NWCA will increase by 1.048 and 1.113 times respectively. This is probably due to the fact that as the farmer gets older in farm work, he accumulates more human capital in the form of experience and increased household members which when re-invested in to the coffee cultivation business will increase yield. Consequently, he will then need a trust worthy route to secure the right income from the sale of his product, which will push him to join the cooperative. This result is in line with that of Tesfamariam (2012) who found out that the number of years as a farmer and in a cooperative positively affected their stay as well as savings in cooperatives. The Centre for International Development Issues Nijmegen (2015) also mentioned that when a reliable buyer is present, timely payment is crucial for the ability of farmers to bypass middlemen. In their study in Uganda, they observed that while farmers sell most of their produce to Ankole (a local cooperative), there are still farmers in the project area who sell to middlemen. This they explained was as a result of the fact that those farmers who sell to Ankole have to wait several days before getting paid. Consequently, when they have urgent cash needs, they find it very difficult to wait for days before being paid money for their coffee, which push them to sell to middlemen rather than the cooperative. In areas where the majority of the household heads have low levels of education $(55.7 \%$ having only primary education and below in our case study), education may not appear to be of significant importance to the inhabitants of the area, especially with regards to socio-economic interactions. This probably explains why the level of education of the farmer did not influence their membership decisions. However, because of this low level of education, most household will therefore rely on agriculture for their livelihoods. Therefore, the fact that $98.6 \%$ of our sample farmers completely rely on agriculture for their household livelihoods explains why in the research area, the main occupation of the household head showed the strongest influence over the decisions of the famers to join NWCA (B = 18.767). This result is similar with that of Buyinza, Banana, Nabanaga and Ntakimye (2008) who found out that farmers' level of adoption of the rotational woodlot technology in Uganda was highly influenced by the main livelihood source of the farmer.

Of significant importance to this study is the ability of NWCA to pay the dues of their members in time $(\mathrm{B}=$ $5.637, \mathrm{P}=0.004)$. As the likelihood of NWCA to pay the dues of members increases by one unit, the probability that more members will join the cooperative increases by 280 times. Thus for farmers with large coffee farms, large households and highly experienced in terms of more farm years, if NWCA can improve on the timely payment of the dues of these coffee farmers, then the higher the probability that these famers will join and continue to be members of the cooperative.

\section{Hypothesis testing}

The following hypothesis was developed and tested, based on the established negative correlation between farm size and transaction costs cum to access farm inputs (Keefer \& Knack, 2005):

$\mathrm{H}_{1}$ : The coffee farm sizes for members are significantly larger compared with those of non-members

$\mathrm{H}_{0}$ : There is no difference in the land used by both members and non-members of NWCA for coffee production

To test the hypothesis, the student t-test statistics was employed, adopting the $95 \%$ confidence interval $(\alpha=0.05)$. Therefore if the $\mathrm{p}$-value of the student $\mathrm{t}$-test statistics on the difference in farm size is less than 0.05 , we reject the null hypothesis but if the p-value of the value of the student t-test statistics on the difference in farm size is greater than 0.05 , we do not reject the null hypothesis. The result of the student $t$-test has been presented in table 6 below; 
Table 6.Student t-test results

\begin{tabular}{llllll}
\hline Variable & Farmer status & Mean & Std. Deviation & Std. Error Mean & t-test \\
\hline Farm size used in & Non-member & 5.034 & 3.1648 & .3607 & $\mathrm{p}=0.004$ \\
coffee production/ha & Member & 6.625 & 2.9268 & .3911 & \\
\hline
\end{tabular}

The results of the student t-test showed significant higher farm size used by members of cooperatives than non-members (men area $=6.625$ for members and 5.034 for non-members, $p=0.004$ ). Based on the results, we reject the null hypothesis and conclude that there exist a significant difference in the land used by both members and non-members for coffee production. In other words, the reasons why farmers are reluctant to join the cooperative can be best explained by other factors than the size of the coffee farm. In fact, the farm size on which coffee is produced had a positive effect on membership decision to join NWCA. This seems justified based on the fact that cooperatives would have lowered transactions working with larger farmers than smaller ones. This is even significant when both parties are involved in long-term relations in which trust becomes crucial (Chaddad, 2012). One the one hand, having larger coffee farms seems to motivate cooperatives to accept farmers' membership. On the other hand, larger assets in the form of land holdings seem to deepen trust, providing informal safeguards on which cooperate behavioral relationships between members and the cooperative can be established (Ménard, 2004, Karantininis, 2007). This seems to resonate with the recent findings of Hasen and Mekonnen (2017), who observedthat the poorest coffee farmers in Eastern Ethiopia were excluded from agricultural cooperatives as production on very small farmers were too small to make membership in cooperatives worthwhile. In fact, the farmers usually opted for self exclusion cooperative membership, especially when the costs of membership were greater than the returns. Similar contentions are held by Thorp, Stewart and Heyer (2005), Francesconi and Heerinck (2010), Asante et al (2011), and Ito et al (2012).

\section{Conclusion and Recommendations}

The objective of this study has been to identify factors that influence the decisions of coffee farmers to join cooperatives. Data was collected from 140 coffee farmers residing intwo divisions in the North West region of Cameroon using a standardized questionnaire. The sample included both (male and female) members and nonmembers of a purposively selected coffee farmers' cooperative, NWCA. The final sample was random, although it was drawn from a frame provided by the cooperative concerned. The collected data also allowed for the characterization of the smallholder coffee sector in the research region. The analysis of the data led to a number of key conclusions. Firstly, coffee is mostly grown as a crop in mixed cropping systems, on coffee farms averaging 6 hectares. This trend mirrors the findings of Joitsa et al (2015) who recently indicated a reduction in coffee production in favor of food crops in the same research region. The majority of sampled coffee farmers (almost 45\%) sell their coffee to independent traders. The coffee cooperative is only a second option, receiving about $41.5 \%$ of farmers' produce. This probably indicates lowered level of trust by such farmers on the cooperative. Secondly, the age of the farmer, number of plots owned, access to credit, educational level the gender of the farmer did not seem to positively affect their membership decisions. Thirdly, household monthly income had no influence on the decisions of the farmers to become members of NWCA $(\mathrm{B}=0.000, \mathrm{P}=$ 0.003).Fourthly, the area of land used for coffee farming, taking farming as main income source, the farmer's household size, experience in coffee farming and the whether the cooperative paid farmers' dues on time contributed positively to the farmers' membership decisions in NWCA. However, only timely payment of farmers' dues by NWCA made a significant contribution. Lastly, the farm size on which coffee is produced was significantly higher among cooperative members than non-members, thus acting as a push factor for joining cooperative.

Given the importance of timely payment of dues, it is strongly recommended that farmers' cooperatives pay more attention to it, if they are interested in consolidating current membership or expanding it. Otherwise, and if smallholder farmers are rational, they may continue to adopt other stop-gap measures (e.g. selling to independent traders for immediate cash returns), especially when discounted demands for current survival supersede any (long term) benefits that may accrue to the farmer, if (s) he joins a cooperative. In addition, NWCA should support smaller farmers in the production process (e.g. through trainings and improved access to farm inputs), in order to encourage them to join the cooperative. Working with smaller farmers in groups can help to offset any increases in transaction costs which the cooperative may want to avoid. Precautions must be taken for generalizing these findings to other cooperatives facing membership problems. As Manning et al (2012) cautioned, the specific context matters. Context-specific analyses are therefore crucial for properly informing policy making decisions, which would favor membership growth beyond this case study. 


\section{Acknowledgements}

The author wishes to acknowledge the Ministry of Higher education in Cameroon, for supporting this project through its regular modernization research grants to University lecturers. The contributions of enumerators and research assistants in data collection and preliminary analysis are also recognized. The author is also thankful to the anonymous referees for their insightful comments on the submitted manuscript, which significantly improved the quality of the final paper.

\section{References}

Abate, G., Francesconi G., \& Getnet, K. (2014). Impact of agricultural cooperatives on Smallholders' technical efficiency: empirical evidence from Ethiopia. Annals of Public and Cooperative Economics, 85(2), 257-286. https://doi.org/10.1111/apce.12035

Abebaw, D., \& Haile, M. G. (2013). The impact of cooperatives on agricultural technology adoption: empirical evidence from Ethiopia. Food Policy, 38, 82-91. http://dx.doi.org/10.1016/j.foodpol.2012.10.003

Armando, C. P. (2009). Agricultural Cooperatives and Farmers Organizations: Role in Rural Development and Poverty Reduction. Annual Report of the Swedish Cooperative Centre, Agricord (Network of international agro-agencies), Sweden, 1-7.

Asante, B., Sefa, V., \& Saprong, D. (2011). Determinants of Small Scale Farmers' Decision to Join a Farmer Based Organizations in Ghana. CSIR- Crops Research Institute. African Journal of Agricultural Research, 6(10), 2273-2279.

Ashenfelter, O., \& Pencavel, J. H. (1969). American trade union growth, 1900-1960. Quarterly Journal of Economics, 86, 434-448. https://doi.org/10.2307/1880530

Azmah O., Fatimah, K., Rohana, J., \& Rosita, H. (2012). Factors Influencing Cooperative Membership and Share Increment: An Application of the Logistic Regression Analysis in the Malaysian Cooperatives. World Review of Business Research, 2(5), 24 - 35

Bacon, C. M., Robert, A. R., \& Hannah, M. (2015), Fair trade coffee and environmental sustainability in Latin America, In L.T. Raynolds, \& A.B. Elizabeth (eds.), Hand book of Research on Fair Trade (388-404). Cheltenham, UK: Edward Elgar Publishing,

Baden, S., \& Pionetti, C. (2011). Women's collective action in agricultural markets: synthesis of preliminary findings from Ethiopia, Mali, and Tanzania. Oxfam Policy on Practical Agriculture and Food Lands, 11(7), $70-126$.

Bagher, A. (2011). Identifying the Factors Affecting the Participation of Agricultural Cooperatives' Members. American Journal of Agricultural and Biological Sciences, 4(6), 560-566

Balgah, R. A. (2018). Do Flood Hazards Affect Risk Attitudes? An Experimental Analysis in AgricultureDependent Communities in Cameroon. Journal of Experimental Agriculture International, 24(3), 1-14. https://doi.org/10.9734/JEAI/2018/42141

Balgah, R. A. (2016). Applying Participatory Rural Appraisal to Unlock Gender Group Differences in Some Communities in Rural Cameroon. Asian Journal of Agricultural Extension, Economics and Sociology, 12(3), 1-11. https://doi.org/10.9734/AJAEES/2016/28327

Balgah, R., Mbue, I., Kimengsi, J., \& Ngwa, K. (2016). Factors Influencing the Adoption of Informal Mechanisms by Disaster Victims in Cameroon. International Journal for Social and Political Science, 2(2), 6-29.

Barrett, C. (2008). Smallholder market participation: Concepts and evidence from eastern and southern Africa. Food Policy, 33, 299-317. https://doi.org/10.1016/j.foodpol.2007.10.005

Bernard, T., \& Spielman, D. (2009). Reaching the rural poor through rural producer organizations? A study of agricultural marketing cooperatives in Ethiopia. Food Policy, 34(1), 60-69. http://dx.doi.org/10.1016/j.foodpol.2008.08.001

Bernard. T., Abate, G., \& Lemma, S. (2013). Agricultural cooperatives in Ethiopia: results of the 2012 ATA baseline survey. Washington, DC: International Food Policy Research Institute. Retrieved from http://citeseerx.ist.psu.edu/viewdoc/download?doi=10.1.1.352.7458

Birchall, J. (2003). Rediscovering the co-operative advantage: poverty reduction through self-help. Geneva, Switzerland: International Labour Organisation. 
Birchall, J., \& Simmons, R. (2008). The Role of Cooperatives in Poverty Reduction: Network perspectives. The Journal of Socio-Economics, 37, 2131-2140. https://doi.org/10.1016/j.socec.2008.04.016

Birchall, J., \& Ketilson, L. (2009). Resilience of the Cooperative Business Model in Times of Crisis, Sustainable Enterprise Programme. Geneva, Switzerland: International Labour Organization,

Bogale, A., \& Shimelis, A. (2009). Household Level Determinants Of Food Insecurity In Rural Areas Of Dire Dawa, Eastern Ethiopia. African Journal of Food Agriculture Nutrition and Development, 9, 1914-1926.

Brice, R. M. (2018). Cameroon: The coffee sector is still declining. Retrieved from https://www.businessincameroon.com/agriculture/0304-7928-cameroon-the-coffee-sector-is-still-declining

Buyinza, M., Banana, A., Nabanoga, G., \& Ntakimye, A. (2008). Socio-economic Determinants of Farmers' Adoption of Ritational Woodlot in Kigorobya Sub-county, Hoima District, Uganda. South African Journal of Agricultural Extension, 37, 1-16.

Centre for International Development Issues Nijmegen (CIDIN). (2014). The Impact of Coffee Certification on Smallholder Farmers in Kenya, Uganda and Ethiopia, Centre for International Development Issues Nijmegen (CIDIN), Radboud University Nijmegen, The Netherlands.

COSA (Committee on Sustainability Assessment) (2013). The COSA measuring sustainability report: Coffee and cocoa in 12 countries. Philadelphia, PA: The Committee on Sustainability Assessment.

Develtere, P., Pollet, I., \& Wayama, F. (2008). Cooperating out of poverty; The renaissance of the African cooperative movement. Washington DC: International Labour Organization/World Bank institute

Divine, M. (2014). Evaluation of factors influencing membership in coffee cooperative in Huye District,Rwanda. Master's Thesis, Nairobi: University of Nairobi, Kenya

Fafchamps, M., \& Vargas-Hill, R. (2005). Selling at the farm gate or travelling to the market?. American Journal of Agricultural Economics, 87(3), 717-734. https://doi.org/10.1111/j.1467-8276.2005.00758.x

Fanaye, T., \& Thomas, A. (2012). Women's Participation in Agricultural Cooperatives in Ethiopia. Washington DC: International Food Policy Research Institute (FPRI).

FAO (2007). National workshop on organic agriculture and fair-trade in Cameroon, SAWA HOTEL, DOUALA CAMEROON, $4^{\text {th }}$ to $5^{\text {th }}$ October 2007.

Fischer, E., \& Qaim, M. (2012). Linking smallholders to markets: determinants and impacts of farmer collective action in Kenya. World Development, 40(6), 1255-1268. http://dx.doi.org/10.1016/j.worlddev.2011.11.018

FLO - Fairtrade Labelling Organizations International (2009). Fairtrade: A better deal. Brochure. [Online] Bonn: Fairtrade Labelling Organizations International. Retrieved from http://www.fairtrade.net/fileadmin/user_upload/content/2009/resources/2010-01_FLOInfoBrochure-EN-2.p df [2010-04-07]. In English

Francesconi, G., \& Heerink, N. (2011). Ethiopian agricultural cooperatives in an era of global commodity exchange: does organisational form matter?. Journal of African Economics, 20(1), 153-177. https://doi.org/10.1093/jae/ejq036

Frederick, D. (1997).Co-ops 101: An Introduction to Cooperatives U.S. Department of Agriculture, Rural Business - Cooperative Service Division, Cooperative Information Report 55. Retrieved from http://www.rurdev.usda.gov/rbs/pub/cir55/cir55rpt.htm (Accessed on 14 August 2018).

Gebremedhin, B., Jaleta, M., \& Hoekstra, D. (2009). Smallholders, institutional services, and commercial transformation in Ethiopia. Agricultural Economics, 40(1), 773-787. https://doi.org/10.1111/j.1574-0862.2009.00414.x

Getnet, K., \& Anullo, T. (2012). Agricultural cooperatives and rural livelihoods: evidence from Ethiopia. Annals of Public and Cooperative Economics, 83(2), 181-198. https://doi.org/10.1111/j.1467-8292.2012.00460.x

Hasen, M., \& Mekonnen, H. (2017). The impact of agricultural cooperatives membership on the wellbeing of smallholder farmers: Empirical evidence from Eastern Ethiopia. Agricultural and Food Economics, 5(6), 1-20. https://doi.org/10.1186/s40100-017-0075-z

Hellin, J., Lundy, M., \& Meijer, M. (2009). Farmer organization, collective action and market access in Meso-America. Food Policy, 34(1), 16-22. http://dx.doi.org/10.1016/j.foodpol.2008.10.003

Hueth, B., \& Marcoul, P. (2009). Incentive pay for CEOs in cooperative firms. American Journal of Agricultural Economics, 91(5), 1218-1223. https://doi.org/10.1111/j.1467-8276.2009.01287.x 
International coffee Council (2015). Sustainability of the coffee sector in Africa, International Coffee Organization, ICC 114-5 Rev. 1, $115^{\text {th }}$ Session, 28 September - 2 October 2015. Milan, Italy

International Labour Office (ILO) (2014). Cooperatives in Africa: Success and Challenges, A Contribution to the International Symposium on Cooperatives and Sustainable Development Goals: The Case of Africa, 2 September 2014, Berlin, Germany

Ito, J., Bao, Z., \& Su, Q. (2012). Distributional effects of agricultural cooperatives in China: exclusion of smallholders and potential gains on participation. Food Policy, 37(6), 700-709. http://dx.doi.org/10.1016/j.foodpol.2012.07.009

Jamilah, D. (2006). Applying Data Envelopment Analysis to Evaluate the Efficiency of Fishermen Associations in Malaysia (unpublished doctoral thesis), University Putra Malaysia, Selangor, Malaysia.

Joitsa, A., Musima, O., \& Yambene, H. (2015). Cooperative movements in the Western Highlands of Cameroon. Journal of Alpine Research. https://doi.org/10.4000/rga.2764

Jussila, I., Byrne, N., \& Tuominen, H. (2012). Affective commitment in cooperative organizations: what makes members want to stay?. International Business Research, 5(100), 1-10. https://doi.org/10.5539/ibr.v5n10p1

Karantininis, K. (2007). The Network Form of Cooperative Organization. In Karantininis, K. \& Nielson, J. (eds), Vertical Markets and Cooperative Hierarchies. Dordrecht: Springer. https://doi.org/10.1007/1-4020-5543-0_2

Karli, A., Bilgic, A., \& Celik, Y. (2006). Factors Affecting Farmers' Decision to Enter Agricultural Cooperatives Using Random Utility Model in the South Eastern Anatolian Region of Turkey. Journal of Agricultural and Rural Development in the Tropics and Subtropics, 107(2), 115-127.

Kumar, V. K., Wankhede, G., \& Gena, H. C. (2015).Role of Cooperatives in Improving Livelihood of Farmers on Sustainable Basis. American Journal of Educational Research, 3(10), 1258-1266. https://doi.org/10.12691/education-3-10-8

Lerman, Z., \& Ruben, R. (2005). Why Nicaruguan Peasants Remain in Agricultural Production Cooperatives. Selected Paper prepared for presentation at the American Agricultural Economics Association Annual Meeting, Providence, Rhode Island.

Lund, M. (2013). Cooperative Equity and Ownership: An introduction. Center for Cooperative, University of Wisconsin, Madison, USA.

Manning, S., Boons, F., von Hagen, O., \& Reinecke, J. (2012). National Contexts Matter: The Co-Evolution of Sustainability Standards in Global Value Chains. Ecological Economics, 83, 197-209. https://doi.org/10.1016/j.ecolecon.2011.08.029

Markelova, H., \& Mwangi, E. (2010). Collective action for smallholder market access: evidence and implications for Africa. Review of Policy Research, 27(5), 621-640. https://doi.org/10.1111/j.1541-1338.2010.00462.x

Ménard, C. (2004). The Economics of Hybrid Organizations. Journal of Institutional and Theoretical Economics, 160(3), 345-376. https://www.jstor.org/stable/40752467

Mojo, D., Fischer, C., \& Degefa, T. (2015). Social and environmental impacts of agricultural cooperatives: evidence from Ethiopia. International Journal of Sustainable Development and World Ecology, 22(5), 388-400. http://dx.doi.org/10.1080/13504509.2015.1052860

Momo-Lekane, G. (2016). Coffee Cooperatives in Cameroon: An Assessment of the Causes of Coffee Cooperatives' Collapse in the Post-adjustment Period, In: Okem A. (eds) Theoretical and Empirical Studies on Cooperatives. SpringerBriefs in Geography. Springer, Cham. https://doi.org/10.1007/978-3-319-34216-0_6

Ngwa, K. A., \& Balgah, R. A. (2016). Determinants of Livelihood Security among Disaster Victims in Rural Cameroon. International Journal of Recent Scientific Research, 7(1), 8328-8334.

Nkechi, C., \& Uchenna, C. (2015). Effects of Membership of Cooperative Organisation and Determinants of Farmer-Members' Income in Rural Anambra State, Nigeria. International Journal of Scientific and Technology research, 4(8), 28-35.

Nugussie, Z. (2009). Why Some Rural People Become Members of Agricultural Cooperatives while others do not. Journal of Development and Agricultural Economics, 2(4), 138-144. 
Nigussie, Z. (2013). Performance Evaluation of Coffee Marketing Cooperatives Union: The case of Chercher Oda Balttom Cooperative Union, West Haraghe, Oromia Region, Ethiopia, Maters Thesis, Department of Cooperative Studies, Makelle University, Ethiopia.

Okwoche, V. A., Osogura, B. C., \& Ckukwudi, P. (2012). Evaluation of Agricultural Credit Utilization by Cooperative Farmers in Benue State of Nigeria. European Journal of Economics, Finance and Administrative Sciences, 47, 123-133.

Osterberg, P., Hakelius, K., \& Nilsson, J. (2007). Members' Perception of their Participation in the Governance of Cooperatives: The Key to Trust and Commitment in Agricultural Cooperatives.

Pierre, K. (2007). The Economics of Fair Trade Coffee: For Whose Benefit? An Investigation into the Limits of Fair Trade as a Development Tool and the Risk of Clean-Washin, HEI Working Paper No: 06/2007, Graduate school of International Studies, Geneva

Poulton, C., Kydd, J., \& Doward, A. (2006). Overcoming market constraints on pro-poor agricultural growth in Sub Saharan Africa. Development Policy Review, 24, 243-277. https://doi.org/10.1111/j.1467-7679.2006.00324.x

Republic of Cameroon (1992). Law no 92-006 of 14 August 1992 relating to Cooperative Societies and Common Initiative Groups. Yaoundé : National Assembly/Presidency of the Republic.

Tuegno, (2016). Interview: Over 25,000 farmers have been certified. Retrieved from https://www.cameroon-tribune.cm/article.html/532/en.html/interview-over-25-000-farmers-have-been

Tesfamariam, K. (2012). Determinants of saving behaviour of cooperative members survey evidence from Tigrai region, Ethiopia. Journal of Research in Economics and International Finance, 1(5), 150-158.

Thorp, R., Stewart, F., \& Heyer, A. (2005). When and how far is group formation a route out of chronic poverty? World Development, 33(6), 907-920. https://doi.org/10.1016/j.worlddev.2004.09.016

Trebbin, A. (2014). Linking small farmers to modern retail through producer organizations-experiences with producer companies in India. Food Policy, 45, 35-44. http://dx.doi.org/10.1016/j.foodpol.2013.12.007

Verhofstadt, E., \& Maertens, M. (2014). Can agricultural cooperatives reduce poverty? Heterogeneous impact of cooperative membership on farmers' welfare in Rwanda. Applied Economics, Perspectives and Policy, 37(1), 86-106. https://doi.org/10.1093/aepp/ppu021

Wanyama, F. O., Develtere, P., \& Pollet, I. (2009). Reinventing the wheel? African cooperatives in a liberalized economic environment. Annals of Public Cooperative Economics, 80(3), 361-392.

https://doi.org/10.1111/j.1467-8292.2009.00390.x

World Bank (2008). World Development Report 2008: Agriculture for Development, The role of Cooperatives. Washington DC: The World Bank.

Zeuli, K., \& Bentancor, A. (2005). The Effects of Cooperative Competition on Member Loyalty. In NCERA-194. Annual Meeting. Minneapolis, Minnesota.

Zeuli, K., \& Cropp, R. (2004). Cooperatives: Principles and practices in the $21^{\text {st }}$ Century. Retrieved from http://learningstore.uwex.edu/assets/pdfs

\section{Notes}

Note 1.According to the OHADA (Organization for the Harmonization of Business Law in Africa) Law of 15 May 2013, there are two types of cooperatives: (1)simplified cooperatives with up to five members, and (2)cooperatives with Board of Directors with at least 15 members (Joitsa et al.,2015).

Note 2.The key legal frameworks include Law no. 73/15 of 7 December 1973 relating to rules and regulations governing cooperative societies; Decree no. 74/874 of 29 October 1974 to establish the conditions of application of law no. 73/15 of 7 December 1973; The Law No 96/006 of 14 August 1992, relating to the establishment and functioning of cooperative societies and common Initiative Groups; and the OHADA Law of 15 May 2013 (Department of Cooperation and Mutuality, 1981, Republic of Cameroon, 1992, Joitsa et al., 2015).

\section{Copyrights}

Copyright for this article is retained by the author(s), with first publication rights granted to the journal.

This is an open-access article distributed under the terms and conditions of the Creative Commons Attribution license (http://creativecommons.org/licenses/by/3.0/). 